\title{
Vascular Endothelial Growth Factor Level as a Predictor of Hepatocellular Carcinoma in Liver Cirrhosis Patients
}

\author{
Benyamin Lukito ${ }^{1}$, Ivet Suriapranata ${ }^{2}$, Pendrianto $^{2}$, Ali Sulaiman ${ }^{3}$, Irawan Yusuf ${ }^{4}$, Budhianto Suhadi ${ }^{5}$, \\ George Mathew ${ }^{2}$, Ferry Sandra ${ }^{6,7,8, *}$ \\ ${ }^{1}$ Department of Internal Medicine, Faculty of Medicine, Universitas Pelita Harapan/Siloam Hospital, Lippo Village, Jl. Siloam No.6, Tangerang, Indonesia \\ ${ }^{2}$ Mochtar Riady Institute for Nanotechnology, Jl. Boulevard Jenderal Sudirman 1668, Lippo Village, Tangerang, Banten, Indonesia \\ ${ }^{3}$ Klinik Hati Prof. Ali Sulaiman, Jl. Cilamaya No. 46, Jakarta Pusat, Indonesia \\ ${ }^{4}$ Department of Physiology, Faculty of Medicine, Hasanuddin University, Jl. Perintis Kemerdekaan Km.10, Makassar, Indonesia \\ ${ }^{5}$ Department of Clinical Pathology, Faculty of Medicine, Universitas Pelita Harapan, Jl. Boulevard Jend. Sudirman, Lippo Village, Tangerang, Indonesia \\ ${ }^{6}$ Department of Biochemistry and Molecular Biology, Faculty of Dentistry, Trisakti University, Jl. Kyai Tapa No.260, Jakarta, Indonesia \\ ${ }^{7}$ BioCORE Laboratory, Faculty of Dentistry, Trisakti University, Jl. Kyai Tapa No.260, Jakarta, Indonesia \\ ${ }^{8}$ Prodia Clinical Laboratory, Prodia Tower, Jl. Kramat Raya No.150, Jakarta, Indonesia \\ *Corresponding author. E-mail: ferrysandra@gmail.com
}

\section{Abstract}

B ACKGROUND: Alpha-fetoprotein (AFP) has been used for hepatocellular carcinoma (HCC) diagnosis and screening, however, AFP has poor specificity. The extensive hypervascularity associated with HCC could be driven in part by the pro-angiogenic factor known as vascular endothelial growth factor (VEGF). Furthermore, invasiveness of certain HCC lesions has recently been linked to high levels of VEGF. Therefore, circulating VEGF levels of patients with liver cirrhosis (LC) and HCC were investigated and analysed.

METHODS: An analytical cross sectional study was designed. Diagnosis of HCC and LC was performed using clinical criteria and findings obtained from B-mode ultrasonography (USG), computed tomography (CT) angiography, or magnetic resonance imaging (MRI). Blood were collected intravenously from all subjects. Obtained serum and plasma were stored in $-80^{\circ} \mathrm{C}$ for following analyses: hepatitis B surface antigen (HBSAg), hepatitis $\mathrm{C}$ virus (HCV), alanine aminotransferase (ALT), total bilirubin, albumin, VEGF and AFP.

RESULTS: Levels of VEGF and AFP were significantly higher in HCC group compared with LC group with $p=$ $3.05 \times 10^{-6}$ and $p=8.74 \times 10^{-5}$, respectively. There was a

\section{Abstrak}

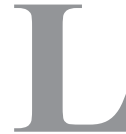

ATAR BELAKANG: Alpha-fetoprotein (AFP) telah digunakan untuk skrining hepatocellular carcinoma (HCC), tetapi spesifisitas AFP kurang baik. Hipervaskularitas yang luas terkait HCC dapat dikendalikan oleh faktor pro-angiogenik yang dikenal sebagai vascular endothelial growth factor (VEGF). Selain itu, tingkat invasif pada lesi HCC tertentu, berkaitan dengan konsentrasi VEGF yang tinggi. Oleh karena itu, konsentrasi VEGF yang bersirkulasi pada pasien dengan liver cirrhosis (LC) dan HCC diteliti dan dianalisis.

METODE: Studi dengan desain potong lintang analitik dilakukan. Diagnosis HCC dan LC dilakukan menggunakan kriteria klinis dan temuan yang diperoleh dari B-mode ultrasonography (USG), computed tomography (CT) angiography, atau magnetic resonance imaging (MRI). Darah diambil secara intravena dari semua subyek dan diproses. Serum dan plasma yang didapatkan disimpan pada suhu $-80^{\circ} \mathrm{C}$ untuk analisis sebagai berikut: hepatitis $B$ surface antigen (HBSAg), hepatitis $C$ virus (HCV), alanine aminotransferase (ALT), total bilirubin, albumin, VEGF dan AFP.

HASIL: Konsentrasi VEGF dan AFP secara signifikan lebih tinggi pada grup HCC dibandingkan dengan grup 
significant positive correlation $(p=0.029, r=0.309)$ between VEGF level and tumor size in HCC group. The area under curve (AUC) for VEGF level in HCC and LC groups was 0.771. In the level of median $435.6 \mathrm{pg} / \mathrm{mL} \mathrm{VEGF}$, the sensitivity was $50 \%$ and specificity was $86 \%$. In the level of $199.99 \mathrm{pg} / \mathrm{mL}$ VEGF the sensitivity was $74 \%$ and specificity was $76 \%$.

CONCLUSION: The present findings suggested that VEGF level could be a useful marker for the presence of HCC in patients with LC.

KEYWORDS: hepatocellular carcinoma, HCC, liver cirhosis, LC, vascular endothelial growth factor, VEGF, alpha-fetoprotein, AFP

Indones Biomed J. 2014; 6(3): 167-74
LC, $p=3.05 \times 10^{-6}$ dan $p=8.74 \times 10^{-5}$, secara berurutan. Terdapat korelasi positif signifikan $(p=0.029, r=0.309)$ antara konsentrasi VEGF dan ukuran tumor pada grup HCC. Area under curve (AUC) untuk konsentrasi VEGF pada grup HCC dan LC adalah 0.771. Pada konsentrasi median VEGF $435.6 \mathrm{pg} / \mathrm{mL}$, sensitivitasnya adalah 50\% and spesifisitasnya adalah 86\%. Pada konsentrasi VEGF 199.99 $\mathrm{pg} / \mathrm{mL}$, sensitivitasnya adalah $74 \%$ dan spesifisitasnya adalah $76 \%$.

KESIMPULAN: Temuan pada penelitian ini menunjukkan bahwa konsentrasi VEGF dapat berguna menjadi penanda akan adanya HCC pada pasien LC.

KATA KUNCI: karsinoma hepatoselular, HCC, liver cirhosis, LC, vascular endothelial growth factor, VEGF, alpha-fetoprotein, AFP

\section{Introduction}

Hepatocellular carcinoma (HCC) is a hypervascular tumor. Abundant and tortuous blood vessels distinguish HCC from benign lesions in angiography.(1) Alpha-fetoprotein (AFP) has been used for many years as a serum marker for HCC diagnosis and screening $(2,3)$, however, in some cases, AFP has poor specificity in the detection of $\operatorname{HCC}(4,5)$. As the result, patients who have liver cirrhosis (LC) need regular examination by abdominal ultrasound and measurement of tumor markers for HCC screening. Since patients with hepatitis $\mathrm{B}$ virus ( $\mathrm{HBV}$ )- or hepatitis $\mathrm{C}$ virus ( $\mathrm{HCV}$ )-related LC are considered high risk, they should be screened every 3-4 months.

Extensive hypervascularity associated with $\mathrm{HCC}$ is thought to be driven in part by the pro-angiogenic factor known as vascular endothelial growth factor (VEGF). $(6,7)$ Furthermore, invasiveness of certain HCC lesions has recently been linked to high levels of VEGF. This leads to a conclusion that there is an important relationship between VEGF and prognosis of HCC.(8,9) VEGF, a 34-46 kDa glycoprotein, has five molecular isoforms generated by alternative splicing of VEGF mRNA.(10) They are 206, 189, 165, 145, and 121 amino acid residues. VEGF121 and VEGF165 are both secreted into the circulation, but VEGF165 is the predominant isoform secreted by most tumors including HCC.(11) Other isoforms do not enter the circulation in a significant amount, because they are either bound to the extracellular matrix (ECM) (VEGF145) or not secreted (VEGF189 and VEGF206).(12) VEGF mediates the secretion and activation of enzymes involved in degrading the ECM. Acting on endothelial cells, VEGF induces expression of plasminogen activator and its inhibitor, urokinase receptor, matrix metalloproteinase, interstitial collagenase and gelatinase A. VEGF also decreases the levels of tissue inhibitors of metalloproteinases 1 and 2.(13) Furthermore, it acts as a survival factor for endothelial cells through inhibition of apoptosis and is essential for mobilization of bone marrow-derived endothelial cell precursors in the promotion of vascularization.(14) VEGF production is upregulated by several substances, including oxygen, steroid hormone, reactive oxygen metabolites and protein kinase $\mathrm{C}$ agonists.(15) VEGF is significantly expressed by sinusoidal endothelial cells and hepatocytes, whereas modest and inconstant expression has been reported for Kupffer cells.(16) VEGF has been shown to induce the proliferation of hepatic sinusoidal cells through increasing expression of its receptors; fms-like tyrosine kinase (FLt) and fetal liver kinase (FLK-1) after experimental partial hepatectomy.(17) VEGF expression increases significantly during the course of liver fibrosis development in experimental studies and that VEGF participated in sinusoidal capillarization in the liver.(18) In addition to hepatocytes, activated hepatic stellate cells, which play an important role in liver fibrogenesis, have been shown to increase VEGF expression during activation.(19) 
Establishment of neovasculature to support HCC growth involves many cell types as liver sinusoidal cells. Kuppfer cells, hepatic stellate cells and circulating endothelial progenitors.(20)

Conflicting data, however, have emerged regarding the ability of VEGF to predict disease progression and overall survival in HCC. This may be related to differences in the methods of measuring and reporting quantitative VEGF measurements. The three most commonly used methods are serum-based VEGF quantitation using enzyme-linked immunosorbent assay, tissue-based semi-quantitative VEGF immunohistochemistry, and tissue-based mRNA measurement.(6) One argument against the use of serum VEGF is the confounding role of platelets, which have been reported to release VEGF into the blood.(21,22) It was found that serum VEGF alone correlated with hepatic tissue VEGF, suggesting that serum VEGF is a useful indirect marker of tumor levels.(12) In recent study, the intraplatelet levels of some angiogenic proteins were reported elevated in cirrhosis, but did not discriminate between patients with and without HCC.(23) Thus, intraplatelet levels of angiogenic proteins seem unuseful as diagnostic or prognostic biomarkers of $\mathrm{HCC}$ in cirrhotic patients.

The aim of this study was to explore the clinical significance of circulating VEGF levels in LC and HCC.

\section{Methods}

\section{Study Design and Sample Collection}

An analytical cross sectional study was designed. Diagnosis of HCC and LC was performed using clinical criteria and findings obtained from B-mode ultrasonography (USG), computed tomography (CT) angiography, or magnetic resonance imaging (MRI). Clinical data including number of nodule and tumor size, were collected. This study protocol was approved by the Health Research Ethics Committee, Faculty of Medicine, Hasanuddin University, Makassar, Indonesia.

\section{Sample Preparation}

Blood were collected intravenously from all subjects. Further process was conducted to obtain serum and plasma. Samples were stored in $-80^{\circ} \mathrm{C}$ for further following analyses: hepatitis B surface antigen (HBSAg), HCV, alanine aminotransferase (ALT), total bilirubin, albumin, VEGF and AFP.

\section{HBSAg, HCV, Total Bilirubin and Albumin Assays}

HBSAg was measured with chemiluminescence microparticle immunoassay (CMIA) using Architect HBsAg assay (Abbott Laboratories, Abbott Park, IL, USA). HCV was measured with enzyme immunoassays (EIA) method using ABBOTT HCV EIA 2.0 (Abbott Laboratories). ALT was measured based on oxidation of NADH to NAD using Activated Alanine Amintransferase (Abbott Laboratories). Total Bilirubin was measured with Diazonium Salt method using Total Bilirubin (Abbott Laboratories). Albumin was measured Bromcresol Purple method using Albumin BCP (Abbott Laboratories).

\section{VEGF Enzyme-linked Immunosorbent Assay (ELISA)}

VEGF was measured with VEGF Human ELISA Kit (ab100663, Abcam, Cambridge, UK). Briefly, it is an in vitro ELISA for the quantitative measurement of Human VEGF. This assay employs an antibody specific for Human VEGF coated on a 96-well plate. Standards and samples are pipetted into the wells and VEGF present in a sample is bound to the wells by the immobilized antibody. The wells are washed and biotinylated anti-Human VEGF antibody is added. After washing away unbound biotinylated antibody, HRP conjugated streptavidin is pipetted to the wells. The wells are again washed, a TMB substrate solution is added to the wells and color develops in proportion to the amount of VEGF bound. The Stop Solution changes the color from blue to yellow, and the intensity of the color is measured at $450 \mathrm{~nm}$. The minimum detectable dose of VEGF is typically less than $10 \mathrm{pg} / \mathrm{mL}$. Recovery was determined by spiking various levels of recombinant Human VEGF into normal tissue lysate and cell lysate. Mean recovery is 95.58 . This ELISA kit shows no cross-reactivity with any of the cytokines tested.

\section{AFP ELISA}

AFP ELISA was conducted with alpha Fetoprotein (AFP) Human ELISA Kit (ab108838, Abcam, Cambridge, UK). This kit is designed for the quantitative measurement of AFP levels. Briefly, an AFP specific antibody were precoated onto 96-well plates and blocked. Standards or test samples were added to the wells and subsequently an AFP specific biotinylated detection antibody was added. Streptavidin-peroxidase complex is added visualized by 3,3',5,5'-Tetramethylbenzidine (TMB) substrate. TMB was catalyzed by the complex to produce a blue color product that changes into yellow after adding acidic stop solution. The density of yellow coloration is directly proportional to the amount of alpha Fetoprotein captured in plate. The 
absorbance was read on a microplate reader at a wavelength of $450 \mathrm{~nm}$.

\section{Statistical Analysis}

Statistical analysis was performed using IBM SPSS Statistics for Windows, Version 21.0 (IBM Corp., Armonk, NY, USA). Receiver operating characteristic (ROC) curves were drawn in order to determine the best cut-off value of serum VEGF and to compare the accuracy of AFP with that of VEGF. A probability less than 0.05 was considered significant.

\section{Results}

From $191 \mathrm{HCC}$ and $204 \mathrm{LC}$ patients, $50 \mathrm{HCC}$ and $50 \mathrm{LC}$ patients were selected. Studied parameters including age, gender, HBSAg, HCV, ALT, Total bilirubin and Albumin were obtained. Higher levels of ALT, Total Bilirubin were

Table 1. General characteristics of LC and HCC groups.

\begin{tabular}{lccc}
\multicolumn{1}{c}{ Parameter } & LC $(\mathbf{N}=\mathbf{5 0})$ & HCC $(\mathbf{N}=\mathbf{5 0})$ & $\boldsymbol{p}$-value* \\
\hline Age & $62.2 \pm 9.6$ & $60.26 \pm 10.11$ & 0.327 \\
Gender (male/female) & $30 / 20$ & $33 / 17$ & 0.539 \\
HBSAg (+/-) & $16 / 34$ & $20 / 30$ & 0.410 \\
HCV (+/-) & $21 / 29$ & $15 / 35$ & 0.215 \\
ALT (IU/L) & $55.74 \pm 51.27$ & $137.14 \pm 101.98$ & $<0.001$ \\
Total Bilirubin (mg/dL) & $2.83 \pm 1.49$ & $5.38 \pm 3.61$ & $<0.001$ \\
Albumin (mg/dL) & $3.13 \pm 0.35$ & $2.9 \pm 0.49$ & 0.007 \\
\hline
\end{tabular}

*: Mann-Whitney U Test

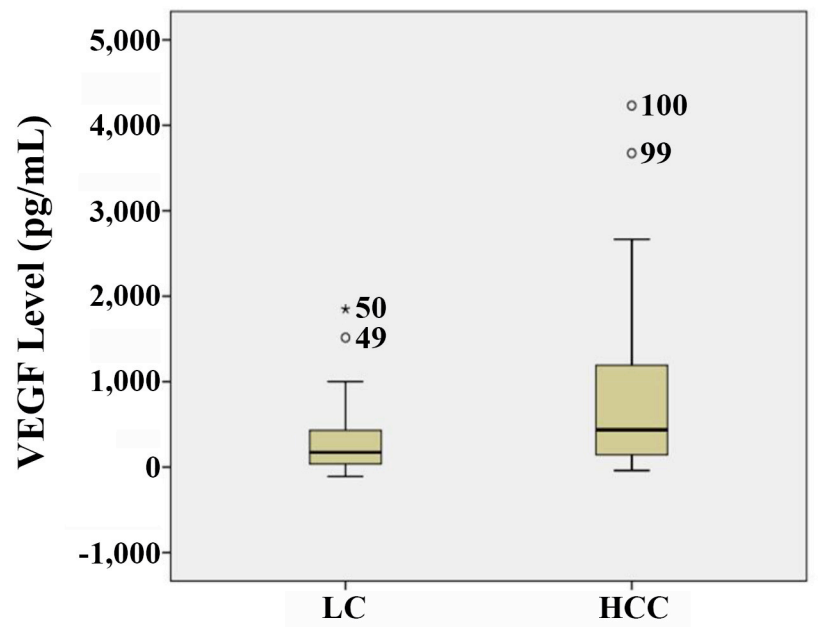

Figure 1. VEGF levels of LC and HCC groups. found in HCC patients. On the other hand, higher levels of Albumin was found in LC patients. There were significant differences in ALT, Total Bilirubin and Albumin levels between LC and HCC groups (Table 1).

Table 2. ELISA results of VEGF and AFP levels in LC and HCC groups.

\begin{tabular}{lrrr}
\multicolumn{1}{c}{ Parameter } & LC $(\mathbf{N}=\mathbf{5 0})$ & HCC $(\mathbf{N}=50)$ & $p$-value* \\
\hline VEGF $(\mathrm{pg} / \mathrm{mL})$ & & $3.05 \times 10^{-6}$ \\
Mean & 359.24 & 852.29 & \\
SD & $1,437.67$ & 977.62 & \\
Minimum & 57.95 & 39.55 & \\
Maximum & $10,209.74$ & $4,230.67$ & \\
\hline AFP (ng/mL) & & & $8.75 \times 10^{-5}$ \\
Mean & 9.30 & $4,167.42$ & \\
SD & 7.01 & $28,264.50$ & \\
Minimum & 1.70 & 2.40 & \\
Maximum & 31.30 & $200,000.00$ & \\
\hline
\end{tabular}

*: Mann-Whitney U Test

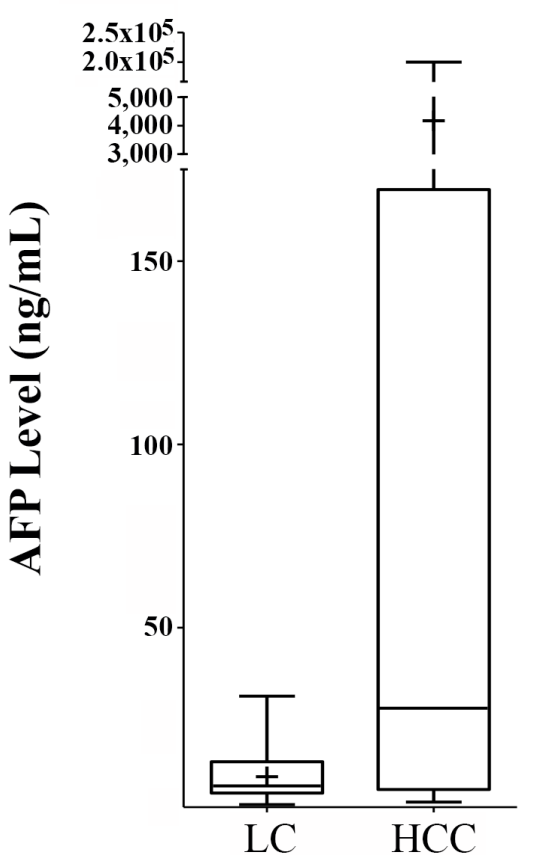

Figure 2. AFP levels of LC and HCC groups.

Our ELISA results showed that mean of VEGF level in HCC group was $852.29 \mathrm{pg} / \mathrm{mL}$ while in LC group was $359.24 \mathrm{pg} / \mathrm{mL}$ (Table 2, Figure 1). Mean of AFP level in 
HCC group was 4,167.42 $\mathrm{ng} / \mathrm{mL}$ while in LC group was $9.30 \mathrm{ng} / \mathrm{mL}$ (Table 2, Figure 2). Levels of VEGF and AFP were significantly higher in HCC group compared with LC group with $p=3.05 \times 10-6$ and $p=8.74 \times 10-5$, respectively.

Table 3. Correlation between VEGF with patient characteristics in HCC group.

\begin{tabular}{lrr}
\hline \multicolumn{1}{c}{ Parameter } & $\boldsymbol{p}$-value* & $\begin{array}{c}\text { Correlation } \\
\text { Coefficient }\end{array}$ \\
\hline Age & 0.222 & 0.176 \\
HBSAg & 0.239 & -0.170 \\
HCV (+) & 0.084 & -0.246 \\
ALT (>100 IU/L) & 0.471 & 0.104 \\
Bilirubin & 0.399 & 0.122 \\
Albumin & 0.916 & -0.015 \\
Number of Nodule & 0.626 & -0.071 \\
Tumor Size & 0.029 & 0.309 \\
\hline
\end{tabular}

*: Pearson and Spearman Test

There was a significant positive correlation $(p=0.029$, $r=0.309$ ) between VEGF level and tumor size in HCC group. However, There was not any significant correlation between VEGF level with age, HBSAg, HCV, ALT, bilirubin, albumin, and number of nodule (Table 3 ).

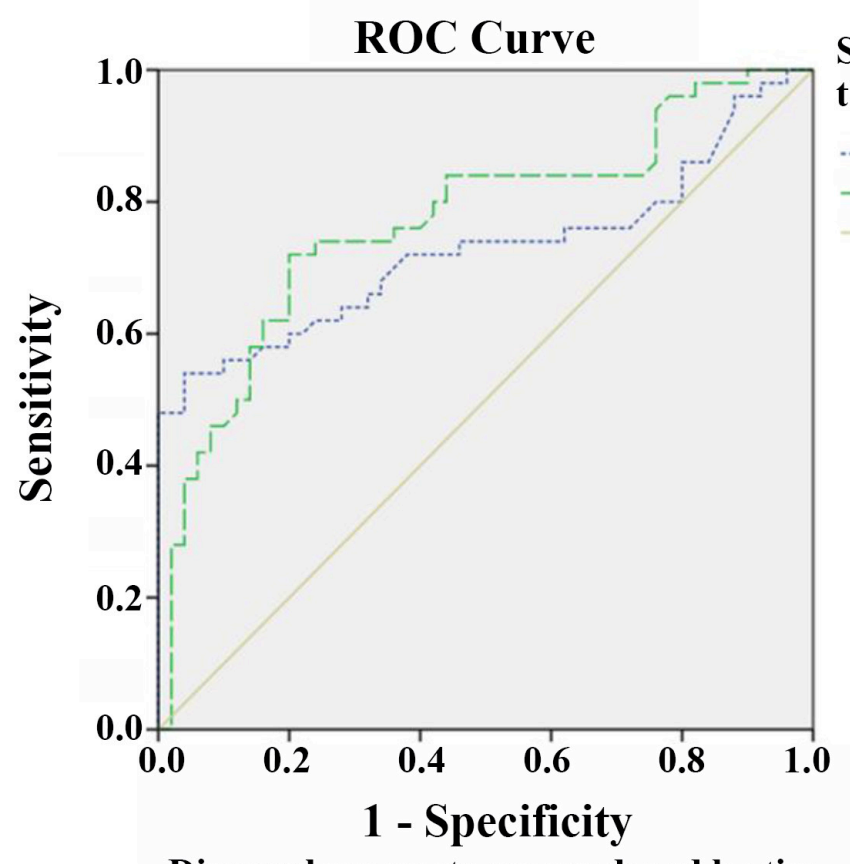

Figure 3. ROC Curve and AUC of VEGF and AFP levels in $\mathrm{LC}$ and HCC groups.

\section{Discussion}

VEGF plays an important role in angiogenesis of many cancers. It has been reported that circulating VEGF is associated with invasion and metastasis in HCC.(24-27) Although VEGF expression in HCC tissues are commonly investigated to estimate VEGF expression (28), currently both tissue and circulating VEGF level have significant predictive value for estimating overall survival in 
hepatocellular carcinoma (29), so that both are useful for defining prognosis in hepatocellular carcinoma.

VEGF protein expression was lower in HCC than in the corresponding non-tumorous liver.(30) However, vascular endothelial cells in tumor tissues show strong immunostaining for VEGF, whereas these cells do not show appreciable staining in non-tumorous tissues. The tumorous vascular endothelial cells with high VEGF expression could be released from HCC. $(31,32)$ VEGF was reported to be involved in neovascularization and infiltration of cancer cells into the tumor capsule in patients with HCC.(33) VEGF levels could be elevated in hypoxia circumstances, leading to tumor progression, therefore oxygen tension plays a major role in VEGF expression. $(34,35)$

In present study, there was significant difference of VEGF levels between HCC and the LC groups. There was also a significant positive correlation between the VEGF level and tumor size. Zhao, et al.(36) and Kamel, et al.(37) also reported that there was a positive correlation between VEGF level and tumor size. Other investigators reported that higher VEGF expression in small HCC and suggested that VEGF plays its most important role in a relatively early stage of angiogenesis. $(38,39)$ Angiogenesis plays an important role in the development and progression of HCC and other tumors.(40) The relation between tumor size and VEGF expression might be complex and dynamic since HCC has different vascular growth patterns. $(40,41)$

In regard to the other tumor markers, it was reported that AFP is produced due to de-differentiation of cancer cells (42); AFP-L3 becomes detectable due to increased fucosylation of AFP due to increased Guanosine diphosphate (GDP)-fucose activity related to upregulation of the $F X$ gene expression in HCC cells (43); and DCP increases because of the low vitamin $\mathrm{K}$ concentration and hypoxia around $\mathrm{HCC}$ cells (44-46). This suggests that the measurement of VEGF level is linking directly to the proliferation of HCC, while other markers indirectly detect the tumor.

The accuracy of the test depends on how well the test separates the group being tested into those with and without the disease. Accuracy is measured by the area under the ROC curve. An area of 1 represents a perfect test; an area of 0.5 represents a worthless test. The AUC for VEGF level in HCC and LC groups was 0.771 which show that the VEGF level in HCC group is different from the VEGF level in LC group.

Kim, et al. (47) in their study comparing AFP in HCC with liver cirhosis to HCC without liver cirhosis, they found that in the level of AFP $\geq 20 \mathrm{ng} / \mathrm{mL}$ the sensitivity was $72.7 \%$ and specificity was $59.7 \%$ and in the level of AFP $\geq 100 \mathrm{ng} / \mathrm{mL} \mathrm{mL}$ the sensitivity was $72.7 \%$ and specificity was $59.7 \%$. In the same way we calculated the sensitivity and specificity of AFP. The AUC of AFP was 0.728. At the same specificity of $92 \%$, the sensitivity for VEGF was $46 \%$ for a VEGF level of $>542.83 \mathrm{pg} / \mathrm{mL}$. Based on VEGF level, we were able to distinguish $\mathrm{HCC}$ from $\mathrm{LC}$, albeit less sensitive than serum AFP level.

The present findings suggested that VEGF level could be a useful marker for the presence of $\mathrm{HCC}$ in patients with LC.

\section{References}

1. Sun HC, Tang ZY. Angiogenesis in hepatocellular carcinoma: the retrospectives and perspectives. J Cancer Res Clin Oncol. 2004; 130: 307-19.

2. Abelev GI. Production of embryonal serum alpha-globulin by hepatomas: review of experimental and clinical data. Cancer Res. 1968; 28: 1344-50.

3. O'Conor GT, Tatarinov YS, Abelev GI, Uriel J. A collaborative study for the evaluation of a serologic test for primary liver cancer. Cancer. 1970; 25: 1091-8.

4. Di Bisceglie AM, Sterling RK, Chung RT, Everhart JE, Dienstag JL, Bonkovsky HL, et al. Serum alpha-fetoprotein levels in patients with advanced hepatitis C: results from the HALT-C Trial. J Hepatol. 2005; 43: 434-41.

5. Ezaki T, Yukaya H, Ogawa Y, Chang YC, Nagasue N. Elevation of alpha-fetoprotein level without evidence of recurrence after hepatectomy for hepatocellular carcinoma. Cancer. 1988; 61: 18803.

6. Sun HC, Tang ZY. Angiogenesis in hepatocellular carcinoma: the retrospectives and perspectives. J Cancer Res Clin Oncol. 2004; 130: 307-19.

7. Pang R, Poon RT. Angiogenesis and antiangiogenic therapy in hepatocellular carcinoma. Cancer Lett. 2006; 242: 151-67.

8. Li XM, Tang ZY, Zhou G, Lui YK, Ye SL. Significance of vascular endothelial growth factor mRNA expression in invasion and metastasis of hepatocellular carcinoma. J Exp Clin Cancer Res. 1998; 17: 13-7.

9. Kanda M, Nomoto S, Nishikawa Y, Sugimoto H, Kanazumi N, Takeda $\mathrm{S}$, et al. Correlations of the expression of vascular endothelial growth factor B and its isoforms in hepatocellular carcinoma with clinico-pathological parameters. J Surg Oncol. 2008; 98: 190-6.

10. Zhao J, Hu J, Cai J, Yang X, Yang Z. Vascular endothelial growth factor expression in serum of patients with hepatocellular carcinoma. Chin Med J (Engl). 2003; 116: 772-6.

11. Ferroni P, Spila A, D’Alessandro R, Martini F, Iacovone F, Ettorre GM, et al. Platelet activation and vascular endothelial growth factor 165 release in hepatocellular cancer. Clin Chim Acta. 2011; 412: 450-4.

12. Poon RT, Lau CPY, Cheung ST, Yu WC, Fan ST. Quantitative correlation of serum levels and tumor expression of vascular endothelial growth factor in patients with hepatocellular carcinoma. Cancer Res. 2003; 63: 3121-6.

13. Ferrara N. Vascular endothelial growth factor as a target for anticancer 
therapy. Oncologist. 2004; 9 Suppl 1:2-10.

14. Asahara T, Takahashi T, Masuda H, Kalka C, Chen D, Iwaguro H, et al. VEGF contributes to postnatal neovascularization by mobilizing bone marrow-derived endothelial progenitor cells. EMBO J. 1999; 18: 3964-72.

15. Assy N, Paizi M, Gaitini D, Boruch Y, Spira G. Clinical implication of VEGF serum levels in cirrhotic patients with or without portal hypertension. World J Gastroenterol. 1999; 5: 296-300.

16. Desideri G, Ferri C. Circulating vascular endothelial growth factor levels are decreased in patients with chronic hepatitis and liver cirrhosis depending on the degree of hepatic damage. Clin Sci (Lond). 2000; 99: 159-160.

17. Ishikawa $\mathrm{K}$, Mochida $\mathrm{S}$, Mashiba $\mathrm{S}$, Inao M, Matsui A, Ikeda $\mathrm{H}$, et al. Expression of vascular endothelial growth factor in non parenchymal as parenchymal cells in rat liver after necrosis. Biochem Biophys Res Commun. 1999; 254: 587-93.

18. Coulon S, Heindryckx F, Geerts A, Van Steenkiste C, Colle I, Van Vlierberghe $\mathrm{H}$. Angiogenesis in chronic liver disease and its complications. Liver Int. 2011; 31: 146-62.

19. Yoshiji H, Kuriyama S, Yoshii J, Ikenaka Y, Noguchi R, Hicklin DJ, et al. Vascular endothelial growth factor and receptor interaction is a prerequisite for murine hepatic fibrogenesis. Gut. 2003; 52: 134754.

20. Chen JA, Shi M, Li JQ, Qian CN. Angiogenesis: multiple masks in hepatocellular carcinoma and liver regeneration. Hepatol Int. 2010; 29; 4: 537-47.

21. Banks RE, Forbes MA, Kinsey SE, Stanley A, Ingham E, Walters C, et al. Release of the angiogenic cytokine vascular endothelial growth factor (VEGF) from platelets: significance for VEGF measurements and cancer biology. Br J Cancer. 1998; 77: 956-64.

22. Webb NJ, Bottomley MJ, Watson CJ, Brenchley PE. Vascular endothelial growth factor (VEGF) is released from platelets during blood clotting: implications for measurement of circulating VEGF levels in clinical disease. Clin Sci (Lond). 1998; 94: 395-404.

23. Alkozai EM, Porte RJ, Adelmeijer J, Zanetto A, Simioni P, Senzolo $\mathrm{M}$, et al. Levels of angiogenic proteins in plasma and platelets are not different between patients with hepatitis $\mathrm{B} / \mathrm{C}$ related cirrhosis and patients with cirrhosis and hepatocellular carcinoma. Platelet. 2014; 1-6. doi: 10.3109/09537104.2014.961415.

24. Jinno K, Tanimizu M, Hyodo I, Nishikawa Y, Hosokawa Y, Doi T, et al. Circulating vascular endothelial growth factor (VEGF) is a possible tumor marker for metastasis in human hepatocellular carcinoma. J Gastroenterol. 1998; 33: 376-82.

25. Li XM, Tang ZY, Qin LX, Zhou J, Sun HC. Serum vascular endothelial growth factor is a predictor of invasion and metastasis in hepatocellular carcinoma. J Exp Clin Cancer Res. 1999; 18: 5117.

26. Poon RT, Ng IO, Lau C, Zhu LX, Yu WC, Lo CM, et al. Serum vascular endothelial growth factor predicts venous invasion in hepatocellular carcinoma: a prospective study. Ann Surg. 2001; 233: 227-35

27. Chao Y, Li CP, Chau GY, Chen CP, King KL, Lui WY, et al. Prognostic significance of vascular endothelial growth factor, basic fibroblast growth factor, and angiogenin in patients with resectable hepatocellular carcinoma after surgery. Ann Surg Oncol. 2003; 10: 355-62.

28. Poon RT, Lau CP, Cheung ST, Yu WC, Fan ST. Quantitative correlation of serum levels and tumor expression of vascular endothelial growth factor in patients with hepatocellular carcinoma. Cancer Res. 2003; 63: 3121-6.

29. Schoenleber SJ, Kurtz DM, Talwalkar JA, Roberts LR, Gores GJ. Prognostic role of vascular endothelial growth factor in hepatocellular carcinoma: systematic review and meta-analysis. $\mathrm{Br}$ J Cancer. 2009; 100, 1385-92.

30. El-Assal ON, Yamanoi A, Soda Y, Yamaguchi M, Igarashi M, Yamamoto A, et al. Clinical significance of microvessel density and vascular endothelial growth factor expression in hepatocellular carcinoma and surrounding liver: possible involvement of vascular endothelial growth factor in the angiogenesis of cirrhotic liver. Hepatology.1998; 27: 1554-62.

31. Plate KH, Breier G, Weich HA, Risau W. Vascular endotherial growth factor is a potential tumour angiogenesis factor in human gliomas in vivo. Nature 1992; 359: 845-8.

32. Brown LF, Berse B, Tognazzi K, Manseau EJ, Van de Water L, Senger DR, et al. Vascular permeability factor mRNA and protein expression in human kidney. Kidney Int. 1992; 42: 1457-61.

33. Mise M, Arii S, Higashituji H, Furutani M, Niwano M, Harada T, et al. Clinical significance of vascular endothelial growth factor and basic fibroblast growth factor gene expression in liver tumor Hepatology. 1996; 23: 455-64.

34. von Marschall Z, Cramer T, Höcker M, Finkenzeller G, Wiedenmann B, Rosewicz S. Dual mechanism of vascular endothelial growth factor upregulation by hypoxia in human hepatocellular carcinoma Gut. 2001; 48: 87-96.

35. Harris AL. Hypoxia - a key regulatory factor in tumor growth. Nat Rev Cancer. 2002; 2: 38-47.

36. Zhao J, Hu J, Cai J, Yang X, Yang Z. Vascular endothelial growth factor expression in serum of patients with hepatocellular carcinoma. Chin Med J (Engl). 2003; 116: 772-6.

37. Kamel L, Nessim I, Abd-el-Hady A, Ghali A, Ismail A. Assessment of the clinical significance of serum vascular endothelial growth factor and matrix metalloproteinase-9 in patients with hepatocellular carcinoma. J Egypt Soc Parasitol. 2005; 35: 875-90.

38. Rosmorduc O, Housset C. Hypoxia: a link between fibrogenesis, angiogenesis, and carcinogenesis in liver disease. Semin Liver Dis. 2010; 30: 258-270

39. Li Q, Xu B, Fu L, Hao XS. Correlation of four vascular specific growth factors with carcinogenesis and portal vein tumor thrombus formation in human hepatocellular carcinoma. J Exp Clin Cancer Res. 2006; 25: 403-9.

40. Coulon S, Heindryckx F, Geerts A, Van Steenkiste C, Colle I, Van Vlierberghe $\mathrm{H}$. Angiogenesis in chronic liver disease and its complications. Liver Int. 2011; 31: 146-162.

41. Jeng KS, Sheen IS, Wang YC, Gu SL, Chu CM, Shih SC, etal. Prognostic significance of preoperative circulating vascular endothelial growth factor $\mathrm{m}$ RNA expression in resectable hepatocellular carcinoma: A prospective study. World J Gastroenterol. 2004; 10: 643-8.

42. Yeh SH, Chen PJ, Lai MY, Chen DS. Allelic loss on chromosomes $4 q$ and $16 q$ in hepatocellular carcinoma: association with elevated alpha-fetoprotein production. Gastroenterology.1996; 110: 184-92.

43. Noda K, Miyoshi E, Gu J, Gao CX, Nakahara S, Kitada T, et al Relationship between elevated FX expression and increased production of GDP-L-fucose, a common donor substrate for fucosylation in human hepatocellular carcinoma and hepatoma cell lines. Cancer Res. 2003; 63: 6282-9.

44. Murata K, Sakamoto A. Impairment of clathrin-mediated endocytosis via cytoskeletal change by epithelial to fibroblastoid conversion in HepG2 cells: a possible mechanism of des- $\gamma$ - carboxy prothrombin production in hepatocellular carcinoma. Int J Oncol. 2008; 33 : 1149-55.

45. Murata K, Suzuki H, Okano H, Oyamada T, Yasuda Y, Sakamoto A. Cytoskeletal changes during epithelial-tofibroblastoid conversion as a crucial mechanism of des- $\gamma$ - carboxy prothrombin production in hepatocellular carcinoma. Int J Oncol. 2009; 35: 1005-14. 
46. Mizuta T, Ozaki I, Eguchi Y, Yasutake T, Kawazoe S, Fujimoto K, et al. The effect of menatetrenone, a vitamin $\mathrm{K} 2$ analog, on disease recurrence and survival in patients with hepatocellular carcinoma after curative treatment: a pilot study. Cancer. 2006; 106: 867-72.

47. Kim KA, Lee JS, Jung ES, Kim JY, Bae WK, Kim NH, et al. Usefulness of serum alpha-fetoprotein (AFP) as a marker for hepatocellular carcinoma (HCC) in hepatitis $\mathrm{C}$ virus related cirrhosis: analysis of the factors influencing AFP elevation without HCC development. Korean J Gastroenterol. 2006; 48: 321-6. 